\title{
Pathogen-regulated genes in wheat isogenic lines differing in resistance to brown rust Puccinia triticina
}

Marta Dmochowska-Boguta', Sylwia Alaba², Yuliya Yanushevska', Urszula Piechota', Elzbieta Lasota', Anna Nadolska-Orczyk ${ }^{3}$, Wojciech M. Karlowski ${ }^{2}$ and Waclaw Orczyk ${ }^{*}$

\begin{abstract}
Background: Inoculation of wheat plants with Puccinia triticina $(P t)$ spores activates a wide range of host responses. Compatible Pt interaction with susceptible Thatcher plants supports all stages of the pathogen life cycle. Incompatible interaction with TcLr9 activates defense responses including oxidative burst and micronecrotic reactions associated with the pathogen's infection structures and leads to complete termination of pathogen development. These two contrasting host-pathogen interactions were a foundation for transcriptome analysis of incompatible wheat-Pt interaction.
\end{abstract}

Methods: A suppression subtractive hybridization (SSH) library was constructed using CDNA from pathogen-inoculated susceptible Thatcher and resistant TCLr9 isogenic lines. CDNA represented steps of wheat-brown rust interactions: spore germination, haustorium mother cell (HMC) formation and micronecrotic reactions. All ESTs were clustered and validated by similarity search to wheat genome using BLASTn and sim4db tools. qRT-PCR was used to determine transcript levels of selected ESTs after inoculation in both lines.

Results and discussion: Out of 793 isolated cDNA clones, 183 were classified into 152 contigs. 89 cDNA clones and encoded proteins were functionally annotated and assigned to 5 Gene Ontology categories: catalytic activity 48 clones (54\%), binding 32 clones (36\%), transporter activity 6 clones (7\%), structural molecule activity 2 clones (2\%) and molecular transducer activity 1 clone (1\%).

Detailed expression profiles of 8 selected clones were analyzed using the same plant-pathogen system. The strongest induction after pathogen infection and the biggest differences between resistant and susceptible interactions were detected for clones encoding wall-associated kinase (GenBank accession number JG969003), receptor with leucine-rich repeat domain (JG968955), putative serine/threonine protein kinase (JG968944), calcium-mediated signaling protein (JG968925) and 14-3-3 protein (JG968969).

Conclusions: The SSH library represents transcripts regulated by pathogen infection during compatible and incompatible interactions of wheat with $P$. triticina. Annotation of selected clones confirms their putative roles in successive steps of plant-pathogen interactions. The transcripts can be categorized as defense-related due to their involvement in either basal defense or resistance through an R-gene mediated reaction. The possible involvement of selected clones in pathogen recognition and pathogen-induced signaling as well as resistance mechanisms such as cell wall enforcement, oxidative burst and micronecrotic reactions is discussed.

Keywords: Bread wheat, 14-3-3 protein, Calcium-mediated signaling protein, Lr gene, Pathogen-induced signaling, Plant-pathogen interaction, Serine/threonine protein kinase SSH, Transcriptome, Triticum aestivum, Wall-associated kinase

\footnotetext{
* Correspondence: w.orczyk@ihar.edu.pl

${ }^{1}$ Department of Genetic Engineering, Plant Breeding and Acclimatization,

Institute - National Research Institute, Radzikow 05-870 Blonie, Poland

Full list of author information is available at the end of the article
} and reproduction in any medium, provided you give appropriate credit to the original author(s) and the source, provide a link to the Creative Commons license, and indicate if changes were made. The Creative Commons Public Domain Dedication waiver (http://creativecommons.org/publicdomain/zero/1.0/) applies to the data made available in this article, unless otherwise stated. 


\section{Background}

Brown rust caused by Puccinia triticina (Pt) is one of the most devastating wheat diseases, responsible for significant yield loses [1]. Resistance breeding is the best economic and ecological approach to control plant diseases. To date, $71 \mathrm{Lr}$ loci conferring resistance to Puccinia triticina $P t$ have been identified in wheat since characterization of the first rust resistance gene in 1946 [2]. Roughly half of them have been found in common hexaploid wheat, while the remaining ones were introgressed from donor species by means of interspecific hybridization (http://www.ars.usda.gov/SP2UserFiles/ ad_hoc/36400500Resistancegenes/Lrgene.xls).

Most of the $L r$ genes have been bred, as a single gene or in combination with others, into wheat to obtain resistant cultivars. Despite the importance of resistance breeding, information about the vast majority of $L r$ genes is derived mostly from plant phenotype analyses. So far, only a small fraction of $L r$ genes have been cloned and characterized. The list includes four genes: $L r 1$, Lr10, $L r 21$ and Lr34. The $L r 1$ gene, located at the distal end of the long arm of chromosome 5D, is part of a large gene family [3]. In contrast, $\operatorname{Lr} 10$ is a single copy gene located on wheat chromosome 1AS and confers enhanced resistance to brown rust [4]. $L r 21$ is located in a gene-rich region of the wheat 1DS chromosome [5]. The three genes, conferring so-called seedling resistance, encode proteins with coiled coil (CC), nucleotidebinding site and leucine-rich repeat (NBS-LRR) domains. Despite similar protein architecture, they show a low (18-21\%) level of amino acid sequence similarity [3]. The Lr34 gene confers adult plant resistance (APR), which remained unbroken by the pathogen for over 50 years. Lr34 protein contains an ATP binding cassette $(\mathrm{ABC})$ domain similar to $\mathrm{ABC}$ transporters which are also known as multidrug resistance (MDR) [6]. The ABC protein encoded by $L r 34$ and the NBS-LRR proteins encoded by $L r 1, \operatorname{Lr} 10$ and $L r 21$ are significantly different considering their architecture and function. It is highly probable that the resistance they provide relies on very different mechanisms. Characterization of only four $\mathrm{Lr}$ genes indicates that the resistance against $P t$ relies on diverse biological mechanisms. Cloning of other genes should widen the range of mechanisms known to be involved in plant resistance. This notion is consistent with the diversity in plant-pathogen interactions as well as different effectiveness and durability of resistance provided by various $L r$ genes and gene combinations [7].

The $\operatorname{Lr} 9$ gene represents an introgression from Aegilops umbellulata and is located on wheat chromosome 6BL [8]. It has been selected for this study because it confers highly efficient resistance, which for a long period remained unbroken by the pathogen. Although there are reports on $P t$ isolates virulent to $L r 9$, the gene is still considered as an important component of efficient brown rust resistance [9]. Analysis of host-pathogen interaction shows that both susceptible Thatcher and resistant TcLr9 plants support the first steps of $P t$ development: i.e. germination of urediniospores, formation of appressoria and development of haustorium mother cells (HMC). Suppression of $P t$ in TcLr 9 begins after formation of haustoria, although the actual recognition takes place shortly after appressoria formation; therefore the resistance is referred to as post-haustorial [10]. In the susceptible Thatcher plants the pathogen life cycle is completed 7-8 days after inoculation, with formation of large uredinia filled with urediniospores. The resistant TcLr9 shows no symptoms of rust infection and no uredinia are formed. Although histopathologically detectable differences between compatible and incompatible interactions are visible only after formation of HMCs $24-48$ h post inoculation (hpi), the reactions of TcLr9 leading to resistance start within a very short time after inoculation [10]. Genes participating in oxidative burst, i.e. peroxidases and NADPH oxidases, are highly induced already 8 hpi. Gene activation corresponds very well with outset of $\mathrm{H}_{2} \mathrm{O}_{2}$ accumulation. Micronecrotic reactions, not detected in Thatcher, were temporally and spatially associated with $87 \%$ of HMCs in resistant TcLr9. Micronecrosis together with oxidative burst represent a strong and localized response leading to efficient inhibition of the pathogen growth and nearly symptomless resistance [10, 11].

Resistance $R$ genes encode proteins responsible for recognition of pathogen/pathogen-associated molecules and lead to incompatible interaction. This requires coordinated regulation of a wide range of defense-responsive $(D R)$ genes and defense processes. The $D R$ genes can be experimentally identified by one of several methods: differential display [12], cDNA-AFLP [13], microarray analysis [14] or suppression subtractive hybridization SSH. The former approach proved to be fruitful in identifying transcripts regulated in diverse plant-pathogen systems: e.g. wheat infected with Fusarium graminearum [15], rice with Xanthomonas oryzae pv. Oryzae [16], barley inoculated with Pyrenospora teres [17] and olive roots colonized with endophytic Pseudomonas fluorescens [18]. The goal of the present study was to identify by the SSH approach transcripts specifically regulated during incompatible interaction of TcLr9 plants with P. triticina.

\section{Methods}

Inoculation of wheat seedlings with brown rust and histopathological analysis

The cultivar Thatcher susceptible to brown rust and the isogenic line carrying the $\operatorname{Lr} 9$ rust resistance gene (TcLr9) [19] were used as plant material for construction of the subtractive cDNA library. The isogenic lines - strongly resistant TcLr26 and medium resistant TcLr24 and TcLr25 
- were used for expression analysis of selected cDNA clones. A single spore isolate of $P$. triticina with an established avirulencefvirulence formula (Additional file 1: Table S4) [10] was used for plant inoculation. The wheat seedlings were grown in a growth chamber at $22{ }^{\circ} \mathrm{C}$ with a $16 \mathrm{~h}$ photoperiod and illumination intensity of $60 \mu \mathrm{E}$ $\mathrm{m}^{-2} \mathrm{~s}^{-1}$. To identify time points crucial in the wheat response to brown rust infection the primary leaves of 7-day-old TcLr9 seedlings were inoculated using a soft brush with spores suspended in water with Tween 20 at a density of $1 \mathrm{mg} \mathrm{ml}^{-1}$ for microscopic observations and $20 \mathrm{mg} \mathrm{ml}^{-1}$ for RNA isolations. Calcofluor white staining and assessment of inoculation efficiency was done using 6 leaves randomly selected from a set of 30 inoculated seedlings. Final spore density on the leaf surface was in the range of $40-150$ spores $\cdot \mathrm{cm}^{-2}$ for microscopic observations. Spore density was assessed by counting 1000-2000 infection sites per leaf. Directly after inoculation, plants were incubated for $24 \mathrm{~h}$ in a dark growth chamber at $18{ }^{\circ} \mathrm{C}$ and $100 \%$ humidity, and then cultivated in the same conditions as seedlings prior to inoculation. Leaf samples of TcLr9, collected 4, 8, $11,16,20,24,28,32,36$ and $44 \mathrm{~h}$ post inoculation (hpi), were stained with calcofluor white as described earlier [10]. Briefly, leaf samples were cleared and fixed in ethanol /dichloromethane $(3: 1 \mathrm{v} / \mathrm{v})$ with $0.15 \%$ trichloroacetic acid for $24 \mathrm{~h}$, washed twice in $50 \%$ ethanol, twice in $0.05 \mathrm{M}$ sodium hydroxide, three times in water, once in $0.1 \mathrm{M}$ Tris- $\mathrm{HCl}$, $\mathrm{pH} 8.5$, and then stained in $3.5 \mathrm{mg} \mathrm{ml}^{-1}$ of calcofluor white dissolved in $0.1 \mathrm{M}$ Tris- $\mathrm{HCl}, \mathrm{pH}$ 9, and washed in water. The stained samples were examined under a fluorescence microscope (Nikon Diaphot, epifluorescence optics with excitation 340-380 nm, barrier filter $420 \mathrm{~nm}$ and dichroic mirror $400 \mathrm{~nm}$ ). These conditions allowed the visualization of pathogen development, i.e. germinating spores, appressoria and haustorium mother cells (HMC). This procedure also allowed detection of the host cell micronecrosis autofluorescence adjacent to HMC. The number of germinating spores, spores forming appressoria, spores forming HMC and the number of necrotic spots with autofluorescence were counted on the whole area of a randomly selected leaf. Results were expressed as the ratio of spores forming appressoria, spores forming HMC and the ratio of necrotic spots to all germinating spores. The upper part of each leaf $(1.5 \mathrm{~cm})$ collected for RNA isolation was stained with calcofluor white to check the efficiency of rust inoculation. Low inoculum density $\left(40-150\right.$ spores $\left.\cdot \mathrm{cm}^{-2}\right)$ facilitating good microscopic observations was applied for leaves used only for histopathological analyses. High inoculum density (described below) was applied for leaves used for RNA extraction.

\section{SSH library construction and differential screening}

To identify wheat genes involved in the response to pathogen infection, leaf samples were collected from the susceptible Thatcher and resistant TcLr9 line 12, 20, 26, 32 and $44 \mathrm{hpi}$. The selected time points represented the most significant plant-pathogen interaction events: 12 hpi marked the presence of appressoria in almost all germinating spores, 20 and 26 hpi the outset of HMC formation and micronecrotic reaction respectively, $32 \mathrm{hpi}$ highlighted the progressive development of all the structures, i.e. appressoria, HMC and micronecrosis, and the final 44 hpi time marked the presence of all the above structures in a well-developed plant-pathogen interaction. To reduce the heterogeneity of the samples the RNA was isolated only from leaves with a high density of germinating spores. This was assessed by calcofluor white staining and spore counting on the middle part of each leaf collected for RNA extraction. Only leaves with over $90 \%$ of stomata accompanied by rust appressoria were used as plant material for RNA extraction. The samples taken from 4 selected leaves from each time point after inoculation were pooled, ground in liquid nitrogen and subjected to RNA extraction using the AGPC (acid guanidinium thiocyanate-phenol-chloroform) method according to a modified procedure described previously [20]. The RNA concentration and the $A_{260} / A_{280}$ ratio were measured with NanoDrop ND-1000 (NanoDrop Technologies, USA). The quality of total RNA was assessed using agarose gel electrophoresis. $5 \mu \mathrm{g}$ of the total RNA was incubated with $2 \mathrm{U}$ of DNase (DNase I recombinant RNase-free, Roche, USA) for $15 \mathrm{~min}$ at $37{ }^{\circ} \mathrm{C}$. DNase was inactivated, according to the manufacturer's protocol by addition of EDTA and heating at $75{ }^{\circ} \mathrm{C}$ for $10 \mathrm{~min}$. The lack of genomic DNA was verified by PCR amplification using $200 \mathrm{ng}$ of DNase digested RNA as a template and PB3/PB4 primers (Additional file 2: Table S1) designed for the wheat $p i n B$ gene [21]. RNA samples giving no detectable $\operatorname{pin} B$ product on agarose gel after 40 cycles of amplification were used for further steps of the procedure.

The DNase digested total RNA extracted from leaves $12,20,26,32$ and 44 hpi were pooled in equal amounts and used for isolation of poly(A) ${ }^{+}$RNA with Oligotex Suspension (Qiagen, USA) according to the manufacturer's protocol. Two poly $(\mathrm{A})^{+} \mathrm{RNA}$ samples obtained from the susceptible cv. Thatcher (driver) and from the resistant TcLr9 (tester) were used for SSH library construction. The library was constructed using the BD PCR-Select cDNA Subtractive Hybridization Kit (Clontech, USA) according to the manufacturer's protocol. After tester cDNA digestion with $R s a \mathrm{I}$ and ligation to adaptor 1 and $2 \mathrm{R}$, two rounds of hybridization and PCR amplification were performed to enrich the differentially expressed sequences. The products of the second round of PCR of subtracted cDNA were cloned into pGEM-T Easy Vector (Promega, USA) using the T/A cloning approach and transformed into Escherichia coli $\mathrm{DH} 5 \alpha$. All E. coli colonies potentially carrying an insert-containing vector were individually selected 
based on the blue/white screening. PCR was performed with $1 \mu \mathrm{l}$ of an overnight bacterial culture as a template and a pair of universal primers, T7/SP6 (Additional file 2: Table S1), flanking the cDNA insert. The PCR products were evaluated in $1.2 \%$ agarose gel electrophoresis to analyze the length of the insert of each clone. Colonies with a confirmed cDNA insert were used to isolate plasmid DNA for differential screening.

Differential screening was performed with the PCRSelect Differential Screening Kit (Clontech, USA) according to the manufacturer's instructions. All cDNA inserts representing individual SSH clones were amplified using isolated plasmid DNA as a template, Nested PCR Primer1 and Nested PCR Primer2R from the BD PCR-Select cDNA Subtractive Hybridization Kit (Clontech, USA) and Taq Platinum DNA Polymerase (Invitrogen, USA). The size and the quantity of the amplification products were examined in agarose electrophoresis. The $100 \mathrm{ng}$ samples of the amplicons, the negative controls of the wheat histone EST and $\mathrm{H}_{2} \mathrm{O}$ as a blank control were mixed with an equal volume of $\mathrm{NaOH} 0.6 \mathrm{~N}$ for alkali denaturation. The samples were manually spotted with a multi-channel pipette on nylon membranes, neutralized with Tris $\cdot \mathrm{HCl}$ $0.5 \mathrm{M}$ (pH 7.5) 2 min, washed with $\mathrm{H}_{2} \mathrm{O}$ and immobilized for $30 \mathrm{~min}$ at $120{ }^{\circ} \mathrm{C}$.

The probe for the differential screening was obtained and quantified using the PCR DIG Probe Synthesis Kit (Roche, USA) according to the manufacturer's protocol. The $50 \mu \mathrm{l}$ synthesis and labeling PCR reaction mix contained $5 \mu \mathrm{l}$ of 10x PCR Reaction Buffer, $2 \mu \mathrm{l}$ of nested PCR primer1 $10 \mu \mathrm{M}, 2 \mu \mathrm{l}$ of nested PCR primer2R (Additional file 2: Table S1) $10 \mu \mathrm{M}, 1 \mu \mathrm{l}$ of $10 \mathrm{x}$ PCR DIG Mix, $34.25 \mu \mathrm{l}$ of $\mathrm{H}_{2} \mathrm{O}, 0.75 \mu \mathrm{l}$ of enzyme mix and $1 \mu \mathrm{l}$ of the template containing $20 \mathrm{ng}$ of cDNA obtained after subtractive hybridization. After the initial denaturation at $94{ }^{\circ} \mathrm{C}$ for $2 \mathrm{~min}, 30$ cycles of amplification were carried out at $94{ }^{\circ} \mathrm{C}$ for $30 \mathrm{~s}, 68{ }^{\circ} \mathrm{C}$ for $30 \mathrm{~s}$, and $72{ }^{\circ} \mathrm{C}$ for $40 \mathrm{~s}$, followed by the terminal extension step at $72{ }^{\circ} \mathrm{C}$ for $7 \mathrm{~min}$. The serial dilutions of the probe and the labeled control DNA provided by the manufacturer were loaded on the nylon membrane and immobilized for $30 \mathrm{~min}$ at $120{ }^{\circ} \mathrm{C}$. Detection was carried out according to the manufacturer's protocol. The membranes were exposed to X-ray film (X-Omat AR, Kodak, USA) for 10-60 min. The amount of the labeled probe was estimated based on the known amount of control DNA. The membrane with the spotted cDNA was hybridized in stringent conditions. It was pre-hybridized with $20 \mathrm{ml}$ of the DIG Easy Hyb (Roche, USA) at $42{ }^{\circ} \mathrm{C}$. After $30 \mathrm{~min}$ the solution was replaced with the hybridization buffer containing the labeled and heat denatured probe. Hybridization was carried out for $20 \mathrm{~h}$ at $42{ }^{\circ} \mathrm{C}$ and was followed by washing with 2x SSC, $0.1 \%$ SDS for $5 \mathrm{~min}$ in $\mathrm{RT}$, twice with $0.5 \mathrm{x}$ SSC, $0.1 \% \mathrm{SDS}$ for $15 \mathrm{~min}$ at $68{ }^{\circ} \mathrm{C}$ and 5 min with washing buffer. DIG detection was done directly after the last washing. The membrane was incubated for $2 \mathrm{~min}$ in $100 \mathrm{ml}$ of maleic acid buffer, $30 \mathrm{~min}$ in $1 \mathrm{x}$ blocking solution (Roche, USA), $30 \mathrm{~min}$ in $20 \mathrm{ml}$ of Anti-Digoxigenin-AP Conjugate dissolved in 1x blocking solution and washed with washing buffer (Roche, USA). Unbound antibodies were removed by 2 min washing in detection buffer and the membrane was evenly covered with $1 \mathrm{ml}$ of CSPD diluted $1 / 100 \mathrm{v} / \mathrm{v}$ in detection buffer. After $5 \mathrm{~min}$ incubation at $37{ }^{\circ} \mathrm{C}$ the membrane was exposed to an X-ray film (X-Omat AR, Kodak, USA) for 10-60 min depending on the strength of the chemiluminescent signals. The results from the hybridizations were recorded for each clone, and those showing the most marked differential expression were selected for sequencing.

\section{Sequencing of EST clones}

Sequencing was carried out by the Laboratory of DNA Sequencing and Oligonucleotide Synthesis, IBB PAS using SP6 and T7 primers. The edited sequences devoid of the primer sequence and the sequencing ambiguities were used to query the GenBank database at NCBI http://www.ncbi.nlm.nih.gov using the BLAST sequence comparison algorithms. The sequences of the wheat cDNA clones identified in this work were deposited in GenBank http://www.ncbi.nlm.nih.gov/Genbank (Additional file 3: Table S2).

\section{Assembly of EST contigs, quality screening and functional annotation}

To remove redundancy and to extend the sequence span the identified EST sequences were used for contig (unique transcripts) assembly along with transcriptomic data (EST, cDNA) from GenBank with the CAP3 program [22]. All EST clusters were validated by similarity search to wheat genome using BLASTn and sim4db tools $[23,24]$. Transcripts showing at least $90 \%$ coverage and $80 \%$ similarity were considered as originating from wheat. Remaining, non-mapping sequences were compared to fungi genomic databases (NCBI nt fungi, JGI MycoCosm and Ensembl Fungi) using provided BLAST-based search tools $[25,26]$. In the next step, all sequence clusters were used for functional annotation. ESTscan [27] was applied for estimation of transcript protein coding potential. For algorithm training data from Brachypodium distachion (dbEST: 128092; UniGene: 10698; RefSeq: 24640) were downloaded from NCBI databases. The predicted wheat peptides were subsequently mapped to the NCBI nr protein database using BLASTp with default parameters [28]. Additionally, all wheat transcripts were mapped to Rfam v10.1 and RepBase v17.04 databases using BLASTn to identify known non-coding RNA sequences and TE derived transcripts, respectively 
$[29,30]$. Assignment of GO terms was based on the 'molecular function' category, because it represents the most detailed information for annotation purposes. The GO terms were extracted from the gene association (GOA) UniProt file, downloaded from the Gene Ontology FTP site [ftp://ftp.ebi.ac.uk/pub/databases/GO/goa/] using the in house developed Python script. In cases where no GO terms could be found in the GOA file, the classification information was manually downloaded from organism-specific databases (e.g. TAIR and Gramene [ftp://ftp.arabidopsis.org/home/ tair/Ontologies/Gene_Ontology/, ftp://ftp.gramene.org/ pub/gramene/CURRENT_RELEASE/data/ontology/go/].

The CateGOrizer tool was used for final reduction of GO terms complexity along with the Plant GO Slim dataset available from the CateGOrizer web [31]. The HMMER3 program with profiles downloaded from Pfam v26.0 [32, 33] was used for prediction of functional protein domains with the e-value parameter set to 0.001 . ESTs with no detectable protein coding potential were scanned for repetitive sequences using the BLASTn program. Repetitive sequences were downloaded from the Wheat Genome Database [34] and Repbase v18.09 repository [30]. Alignments covering at least $40 \%$ of the EST sequence with more than $70 \%$ identity were considered as TE-related. Transcripts without assigned function were tested for sRNA coding potential. The microRNA sequences from miRBase v18.0 and Triticum aestivum sRNA-Seq data from the GEO database (GSE36867, GSE32476, GSE27327, GSE22048 and GSE16177) were mapped onto assembled EST transcripts with the BLASTn program using parameters adjusted for short sequences (-word_size 6 -gapopen 3 -penalty -1) [35, 36]. Only sequences originating from a forward strand without mismatches were considered.

\section{Quantitative RT-PCR}

Quantitative RT-PCR was used to determine transcript levels of selected ESTs at the particular time point after inoculation in both isogenic lines. The leaves collected 0 , $8,16,24,32$ hpi and 2, 3, 4 and 5 days post inoculation (dpi) were stained with calcofluor white to verify high density of germinating spores. RNA extraction, DNase digestion, and checking RNA purity from genomic DNA were done as for SSH library construction. Leaf RNA extracted from 3 independently inoculated seedlings represented 3 biological repetitions of expression profiling. The reverse transcription reaction was performed using the Revert Aid First Strand cDNA Synthesis Kit (Fermentas, Lithuania) according to the manufacturer's protocol. The cDNA samples were diluted 20x and directly used as templates for qPCR.

The standard qPCR reaction mix was composed of: $5 \mu \mathrm{l}$ of the mastermix (2x Sso-Fast Eva Green Supermix,
Bio-Rad Laboratories, Hercules, USA), $0.3 \mu \mathrm{l}$ of primer F $(10 \mu \mathrm{M}), 0.3 \mu \mathrm{l}$ of primer $\mathrm{R}(10 \mu \mathrm{M}), 1 \mu \mathrm{l}$ of cDNA and $3.4 \mu \mathrm{l}$ of water. The reactions were performed in a Corbett Rotor-Gene 6000 5-plex thermocycler in conditions summarized in Additional file 2: Table S1. A melting curve analysis $\left(72{ }^{\circ} \mathrm{C}\right.$ to $\left.95{ }^{\circ} \mathrm{C}\right)$ was performed to ensure the specificity of the amplification. The size of each amplicon was verified by gel electrophoresis. Transcript quantitation in each analyzed combination of isogenic line and the time point was done in three independent biological replications and each reaction was run in three technical repetitions. Concentrations ranging from $10^{5}$ to $10^{11}$ copies of analyzed amplicon per reaction were used as the standards for $18 \mathrm{~S}$ and $10^{2}-10^{8}$ copies per reaction for other genes. Reaction efficiencies (RE) were between 0.8 and 1.1. Relative expression of the analyzed gene was calculated by two standard curves method with 18S rRNA as a reference using Rotor-Gene 6000 software $\mathrm{v}$ 1.7. For statistical comparison ANOVA followed by Tukey's post-hoc test was used (STATISTICA 10, StatSoft). Only $p$ values $<0.05$ were considered as statistically significant.

\section{CVTR}

In order to compare the possible impact of the expression of each analyzed gene on host-plant interaction the cumulative value of transcript rate (CVTR) was used as described previously [11]. The CVTR denoted the total transcript accumulation rate during 5 days of infection and was calculated as the definite integral of the function of the accumulation rate between 0 and $5 \mathrm{dpi}$. The calculated value represents the area below the graph of the accumulation rate delimited by time 0 and $5 \mathrm{dpi}$ for each gene. Since the CVTR takes into account both the transcript accumulation rate and the duration of expression, it allows for a direct comparison of all genes in tested lines. This enables the evaluation of the impact of genes' expression on the analyzed process. The Spearman correlation coefficient was calculated (using Statistica version 10, StatSoft) between the ranked variables of the CVTRs of the analyzed SSH clone in susceptible Thatcher, medium resistant (TcLr24, TcLr25) and highly resistant (TcLr9, TcLr26) lines.

\section{Results}

\section{Determination of time points crucial for plant-pathogen interaction}

To identify time points crucial in the plant response to pathogen infection, seedlings of the resistant line Tc $L r 9$ were inoculated with brown rust spores. The leaf samples, collected $0,4,8,11,16,20,24,28,32,36$ and 44 hpi were used for histopathological analysis (Fig. 1). The percentage of germinating spores that formed appressoria and haustorium mother cells (HMCs), as well as the 

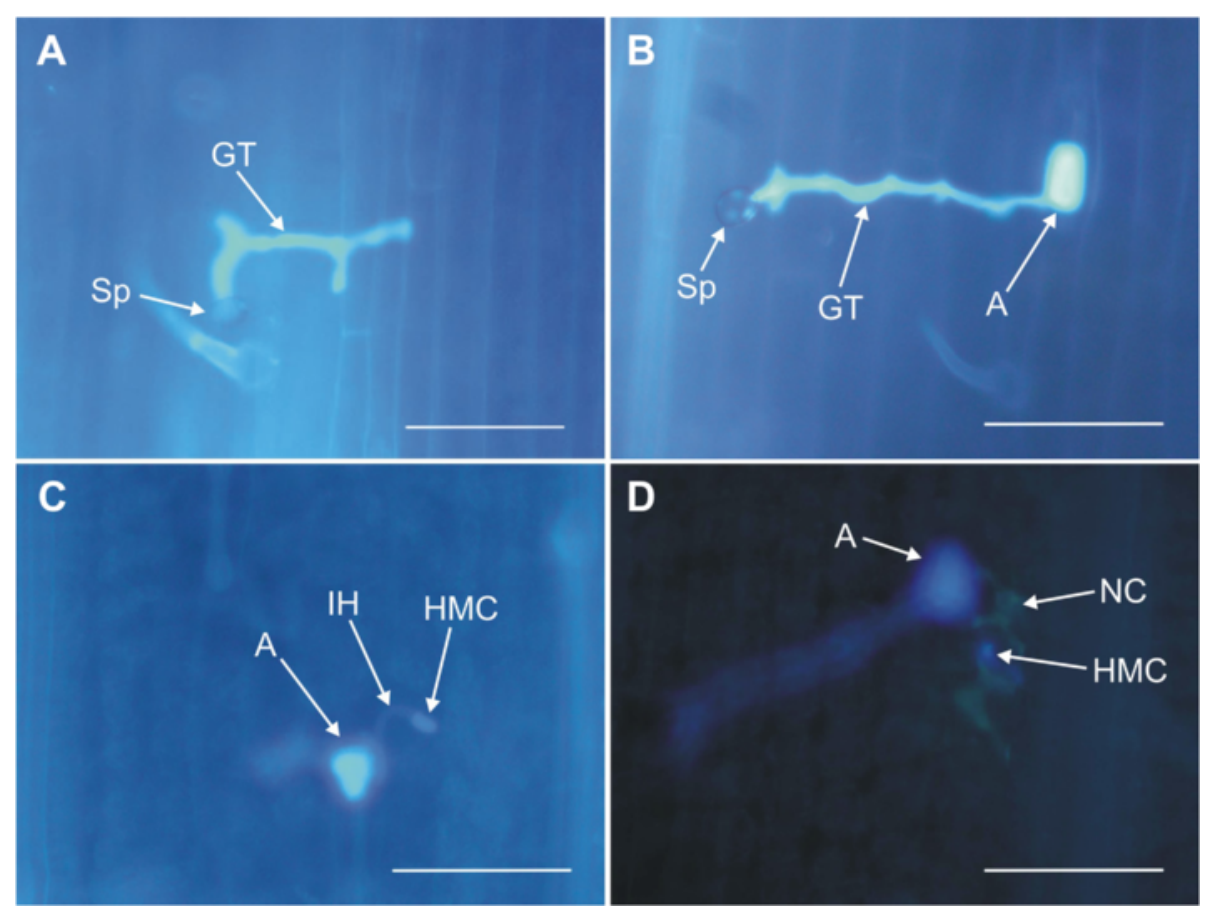

Fig. 1 Microscopic visualization of brown rust (P. triticina) spore development and micronecrotic reaction of plant cells adjacent to haustorium mother cell (HMC) in TCLr9. Leaves of 7-day-old seedlings were inoculated with brown rust spores. Leaf samples, collected 4, 8, 11, 16, 20, 24, 28, 32, 36 and $44 \mathrm{~h}$ post inoculation (hpi), were stained with calcofluor white and analyzed under a fluorescence microscope. Representative images are shown with germinating spore, 4 hpi (a), appressorium on the guard cells, 4 hpi (b), haustorium mother cell, 16 hpi (c), necrotic cells formed near haustorium mother cell, 28 hpi (d). Indicated are: spore of brown rust (Sp), germ tube of a germinating spore (GT), appressorium (a), infection hypha (IH), haustorium mother cell (HMC), and necrotic cells (NC). Bar $=100 \mu \mathrm{m}$

percentage of infection sites with micronecrotic reactions, was scored.

The fraction of spores forming appressoria was $4.9 \%$ at 4 hpi and $54.4 \%$ at 8 hpi. Between 11 and 44 hpi the value ranged from $56.8 \%$ to $81.6 \%$. The first haustorium mother cells (HMCs) were detected 16 hpi. The portion of spores with HMCs at 16 hpi was $0.4 \%$ and this value steadily increased to $68 \%$ at 44 hpi. Necrotic cells adjacent to HMCs, which indicated a plant response to the pathogen infection, were detected at 28 $\mathrm{hpi}$, and the percentage of spores inducing a necrotic reaction was $3.8 \%$. This value was $23.9 \%$ at $32 \mathrm{hpi}$ and increased to $58.1 \%$ at 44 hpi (Fig. 2).

Total RNA for SSH library construction was extracted from leaves collected 12, 20, 26, 32 and 44 hpi. The selected time points represent the most important steps of plant-pathogen interaction. The first one (12 hpi) represented the high percentage of germinating spores, shortly before formation of HMCs. The time point 20 hpi represented the beginning of HMC formation, and 26 hpi marked the high ratio of HMCs, shortly before the necrotic reactions. Progressive development of micronecrotic reactions, i.e. the plant response, closely associated with formation of HMCs, was significant at
32 hpi. The high ratio of HMCs and strong necrotic response were the most important features at $44 \mathrm{hpi}$ (Fig. 2).

\section{SSH library construction and identification of differentially expressed clones}

The uniform inoculation of both isogenic lines was confirmed by microscopic observation of germinating spores in leaf samples stained with calcofluor white. To ensure proper pathogen-induced gene expression in analyzed samples, total RNA was isolated from leaves with confirmed high density of germinating spores (results not included). Only leaves where 70-90\% of guard cells were occupied by appressoria were used for RNA isolation and for further analysis (Fig. 3).

In total 793 cDNA clones were isolated and subjected to differential screening by hybridization with DIGlabeled probes (Fig. 4). 247 EST clones represented by the most marked differential expression (see examples shown in Fig. 4) were selected for sequencing and further analysis. After initial evaluation and quality screening, 183 selected clones were deposited in GenBank http://www.ncbi.nlm.nih.gov/Genbank (Additional file 3: Table S2). 


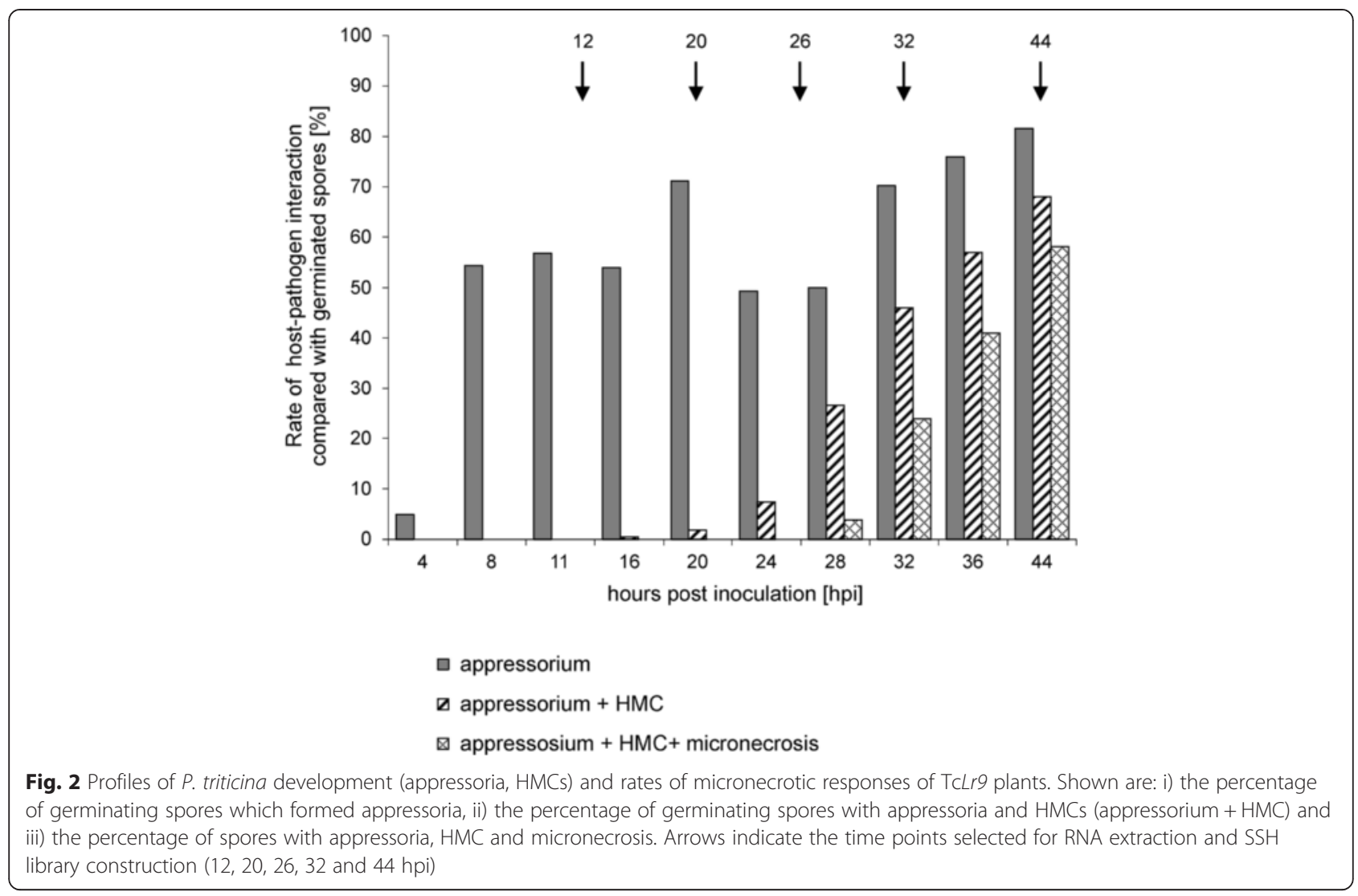

\section{Gross functional annotation of EST tags}

The EST sequences were mapped to the wheat genome and available fungal sequences to detect putative contaminations. Only one sequence (JK818344_JK818346) could not be mapped to any reference dataset and it did not reveal any significant similarity to publicly available sequences. Two sequences (JK818343 and JK818359) show strong similarity to the $P$. triticina genomic sequence and represent differentially expressed pathogen transcripts. No function could be assigned to them based on conserved domain screening and similarity searches (see later). 183 EST clones were assembled into 152 unique transcripts (contigs; see Materials \& Methods). 113 out of 152 clustered EST sequences show protein coding potential when analyzed with ESTscan trained on Brachypodium distachyon sequences. The average predicted protein length was 135 aa, with maximal and minimal size of 271 and 34 aa, respectively. Additionally, 16 contigs were classified as protein-coding based on a BLASTx search. In total 129 out of 152 sequences (85\%) were
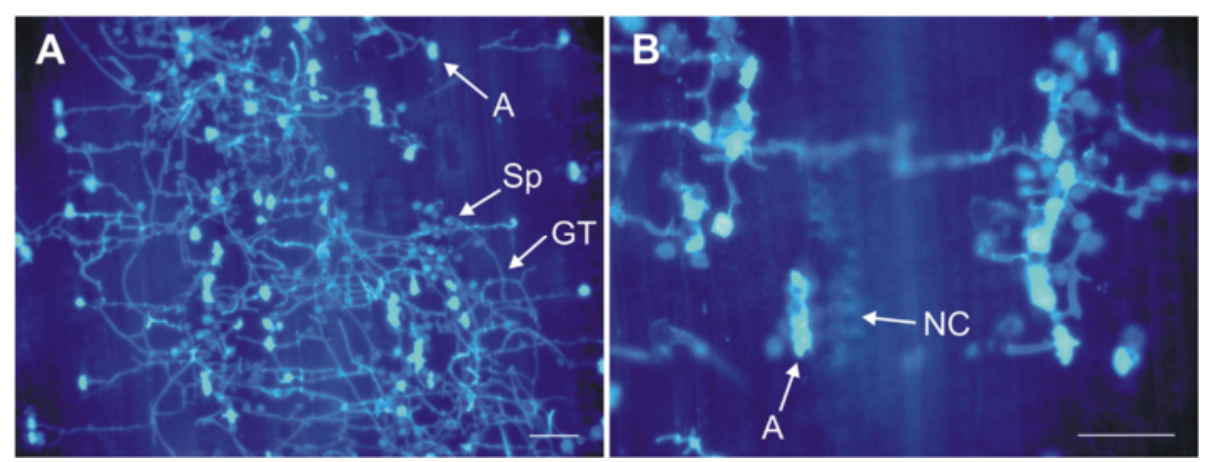

Fig. 3 Microscopic picture of leaf samples with high density of germinating P. triticina urediniospores (a), higher magnification of high density urediniospores with visible necrotic cells (b). Indicated are: spore of brown rust (Sp), germ tube of a germinating spore (GT), appressorium (A), necrotic cells (NC). Bars $=100 \mu \mathrm{m}$ 


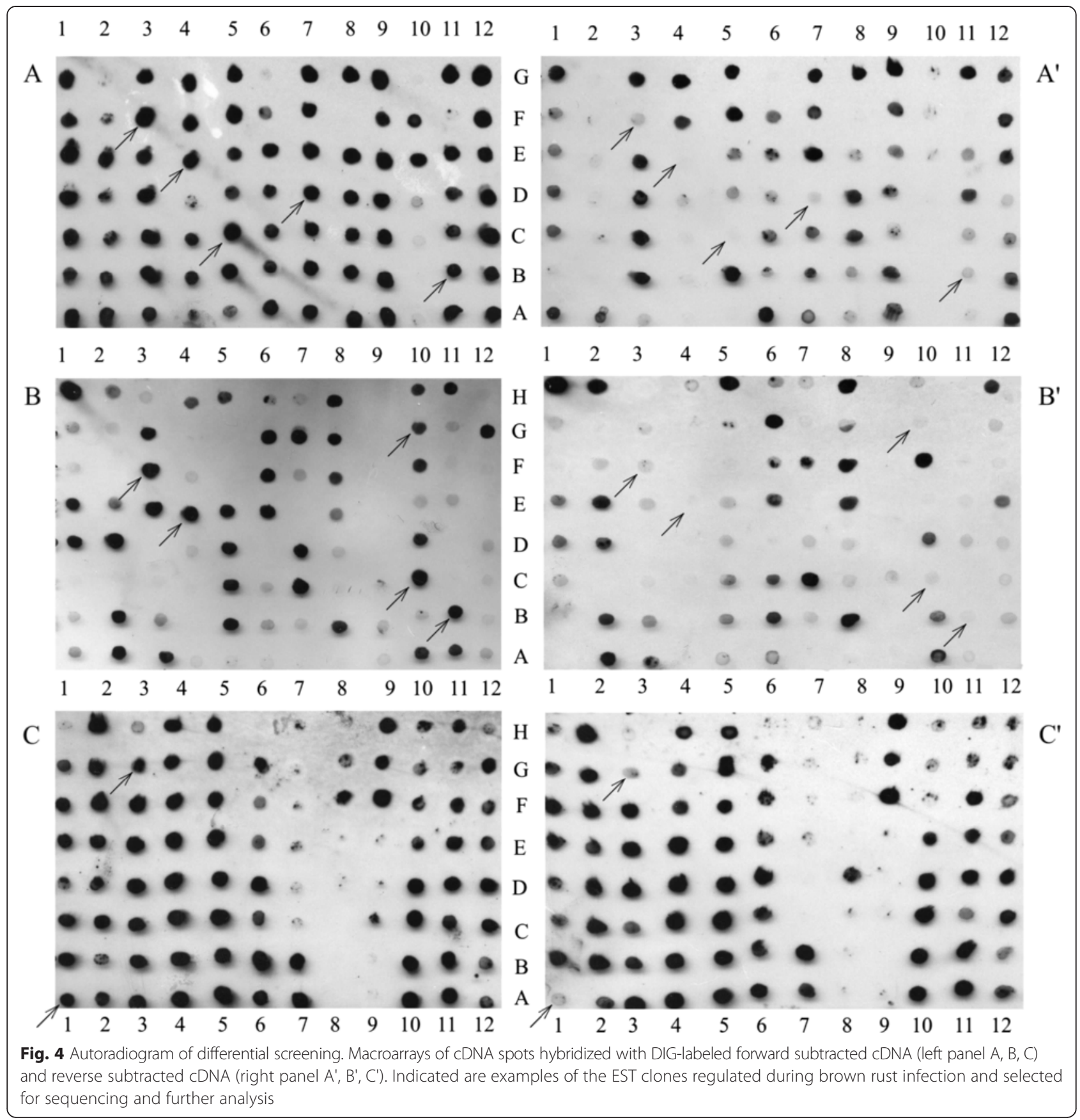

predicted to encode proteins. Analysis of the protein sequences with the Pfam database for presence of functional domains allowed the identification of at least one motif in 82 sequences. Among them 3 clones (JK818321_JK818338, JG969002_JG968938_JG968937, JG968929) show complex domain architecture with 5 different functional amino acid motifs. The Gene Ontology classification system was used to annotate 89 of the tested proteins (Fig. 5). Among them the most represented categories were 'catalytic activity' and 'binding'. The predicted molecular activities included 'oxidation-reduction processes,' 'phosphorylation,' 'transport processes', 'protein folding' as well as 'responses to stress' and 'regulation of transcription and translation'. 11 sequences were predicted to be localized in plastids and 24 show properties characteristic for membrane proteins.

The remaining, non-protein coding transcripts were analyzed with mature miRNA data from miRBase. Only one fragment (JG968965) showed weak (three mismatches) similarity to gma-miR862b. The next-generation 


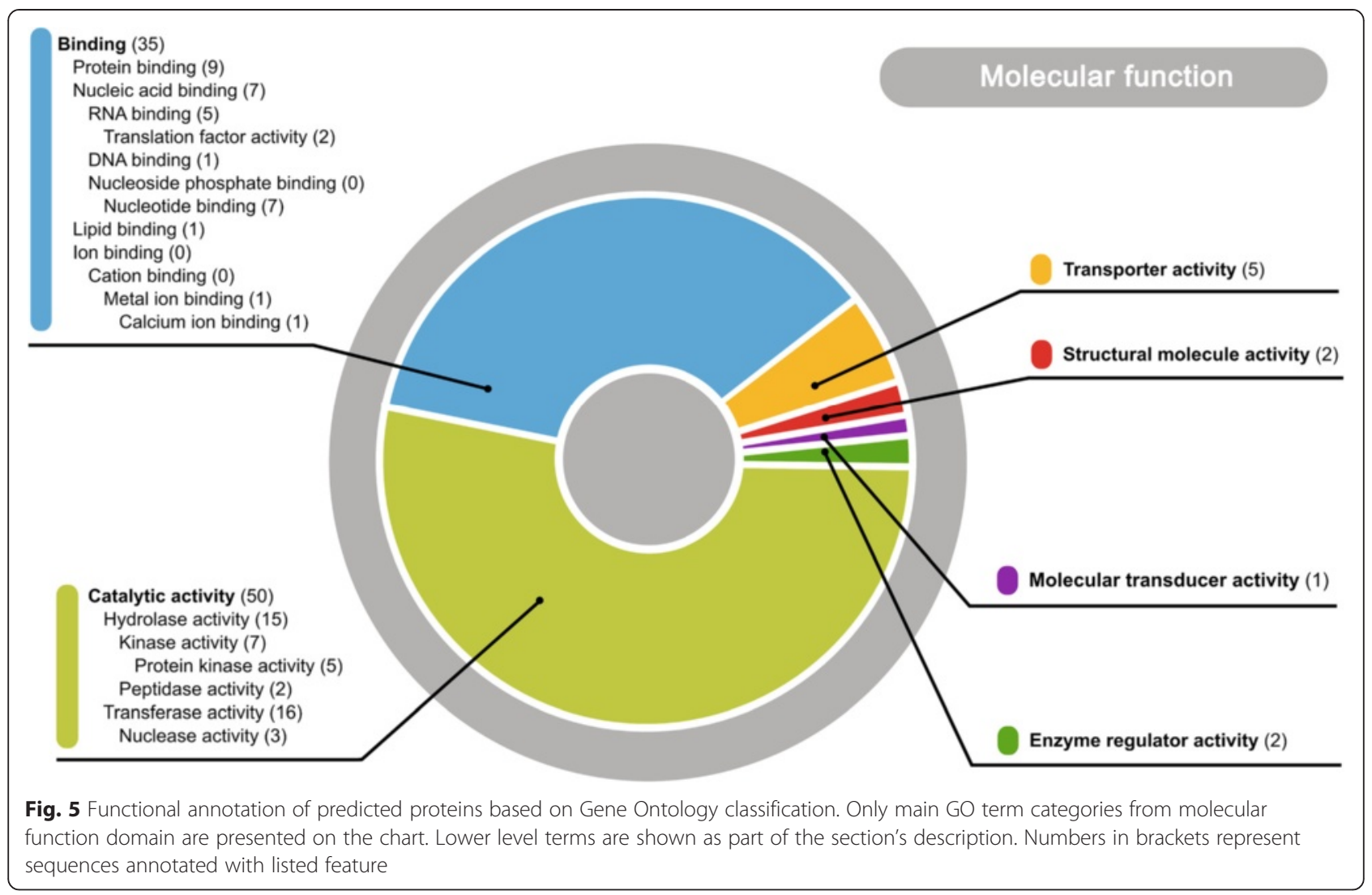

sequencing (NGS) data (GEO accession numbers: GSE36867, GSE32476, GSE29243, GSE27327, GSE22048 and GSE16177) did not confirm the presence of any miRNA-like molecule originating from this transcript.

Further analysis with sRNA sequencing data resulted in the identification of three additional transcripts with putative miRNA coding potential. JK818366 displayed a short read mapping pattern resembling the $\mathrm{miR} / \mathrm{miR}^{*}$ duplex. However, this sequence fails to fold into a canonical hairpin structure. Two other EST sequence clones (JK818342 and JK818383) form proper hair-pin structure but their sRNA coding capacity could not be unambiguously confirmed in NGS sequencing data. Using the plant repeated sequence resources (see Methods), we were able to identify one of the contigs as a transcript derived from a transposable element. The JK818394 sequence shows the highest similarity to the Gypsy-3-LTR family and encodes a putative 138 amino acid (aa) peptide. Interestingly, the predicted aa sequence does not display any similarity to known proteins, with the exception of a 26 aa fragment, which is highly similar to calcium/calmodulin-dependent serine/ threonine-protein kinase 1 from Triticum urartu. Combined results of gross functional annotation are presented in Additional file 4: Table S3.

\section{Modeling the roles of differently expressed genes during the pathogen response}

Pathogen infection recognized by host receptors initiates a signaling pathway and triggers a complex host response. The cDNA clones identified in the wheat subtractive library represent genes involved in different phases of the plant-pathogen interaction (Fig. 6). Plant recognition of pathogen infection depends on interaction of host receptors with pathogen-derived or pathogen-induced elicitors. This step, necessary for triggering the host response, is mediated by receptor-like protein kinases (RLKs), proteins with nucleotide-binding site-leucine-rich repeat (NBS-LRR) domains and wall-associated kinases (WAKs). Twenty identified clones represent a putative protein kinase including mitogen-activated protein MAP kinase and five clones represent a putative receptor-like wallassociated kinase or receptor with an LRR domain.

Twelve clones represent transcripts involved in oxidation reduction processes. The putative respiratory burst oxidase homologue Rboh (JG968934) encodes a crucial enzyme responsible for generation of reactive oxygen species (ROS) during pathogen-induced oxidative burst. Clone JK818365 represents an MAP kinase responding to hydrogen peroxide and possibly participating in ROSdependent signal transduction. 


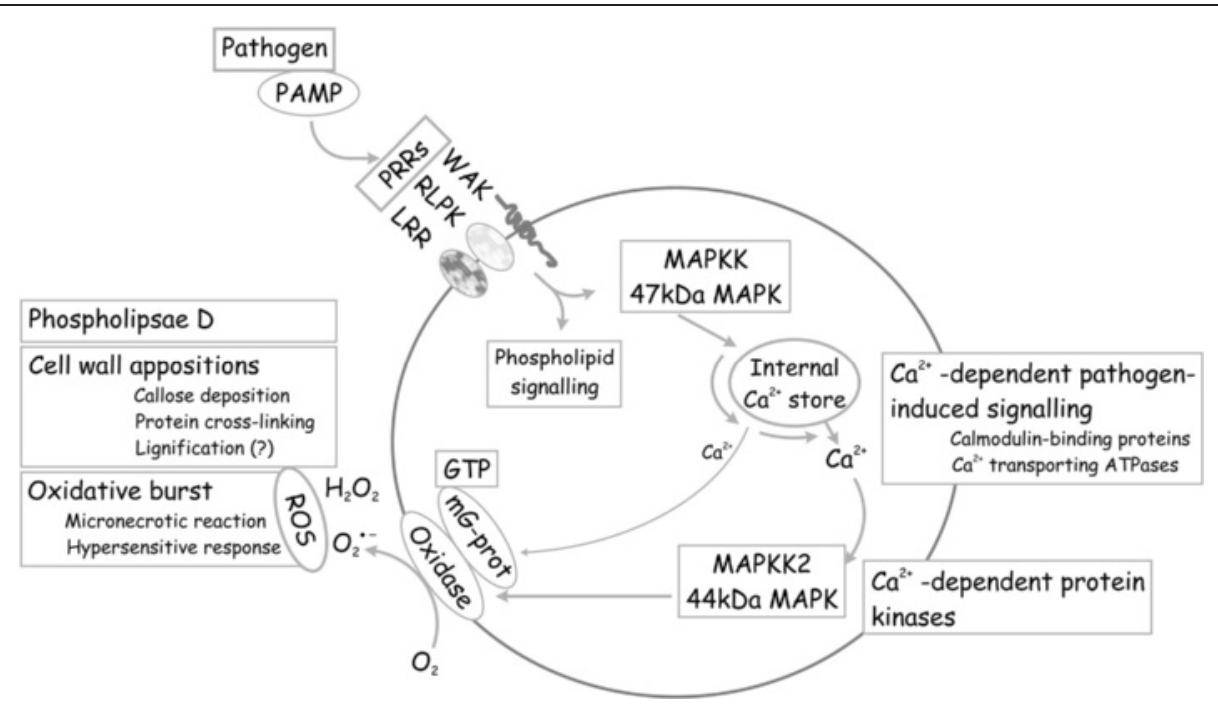

Fig. 6 Schematic representation of pathogen-induced signal transduction pathways. The indicated components of the pathway are: pathogen associated molecular pattern PAMP (pathogen-derived elicitor), pattern recognition receptors PPR, MAP kinases and protein kinases, components of calcium-dependent pathogen-induced signaling and components of oxidative burst

A group of 12 clones represent transcripts involved in calcium-dependent signaling. This group includes cluster JG968933_JK818362 with $\mathrm{Ca}^{2+}$ and ATP-binding activity and a cell wall localization domain. Clones possibly involved in pathogen-induced phospholipid signaling are represented by 4 clones. Clone JG968941 encodes callose synthase, a key enzyme necessary for pathogeninduced callose deposition and cell wall enforcement.

\section{Expression profiles of selected clones}

Expression of the putative receptor like wall-associated kinase TaWAK (JG968933) is strongly induced in wheat inoculated with brown rust. The expression, much stronger in resistant lines ( $\operatorname{Lr} 9, \operatorname{Lr} 24, \operatorname{Lr} 25$ and $\operatorname{Lr} 26)$ than in the susceptible Thatcher, clearly differentiates medium (TcLr24, TcLr25) and highly resistant (TcLr9, TcLr26) lines (Fig. 7). Wall-associated kinases are also represented by two other clones, JG969003_JG968950 and JG968951. Expression of both is pathogen dependent. The first one, JG969003, is transiently induced in inoculated leaves of susceptible Thatcher and strongly and stable activated in resistant TcLr9 (Fig. 8a). The second, WAK encoding clone (JG968951) shows increasing expression in both Thatcher and the resistant line, although the differences between the two lines were not statistically significant (Fig. 8b). The transcript level in the plantpathogen system is often site-specific and is localized in the cells surrounding the infection site. Thus the expression level depending on the actual inoculum density might vary in the biological repetitions. The results of our earlier gene profiling [11] indicate that this as well as the natural variability of two living and interacting organisms might result in relatively large standard errors at certain experimental time points.

The cumulative value of transcript rate (CVTR) was introduced to compare expression profiles of tested $\mathrm{SSH}$ clones and to evaluate their possible impact on plantpathogen interaction in a particular line. The TaWAK (JG968933) CVTRs correlated with the resistance levels of the tested lines. The lowest value was established in susceptible Thatcher, intermediate were in medium resistant (TcLr24, TcLr25) and the highest were in highly resistant (TcLr9, TcLr26) lines. The Spearman correlation coefficient of the ranked resistance levels and the CVTRs of TaWAK (JG968933) was 0.947 and the significance level $p=0.014$ (Table 1 ).

A putative receptor with a leucine-rich repeat (LRR) domain (JG968955) is strongly and transiently induced at 8-16 hpi in both susceptible and resistant plants. The first upregulation peak is followed by a second one 3-4 dpi. Although the expression pattern is similar in both lines, the relative transcript level in the resistant TcLr9 is over twice as high as in the susceptible Thatcher (Fig. 8c). Expression of putative serine/threonine protein kinase (JG968944) in the susceptible Thatcher shows temporal induction $24 \mathrm{hpi}$. Expression of the clone in resistant TcLr9 after a strong initial induction 32 hpi remained elevated for 5 days after inoculation (Fig. 8d).

An important part of the pathogen-induced response depends on calcium-mediated signaling. The expression profile of putative calcium ion binding calreticulin, encoded 

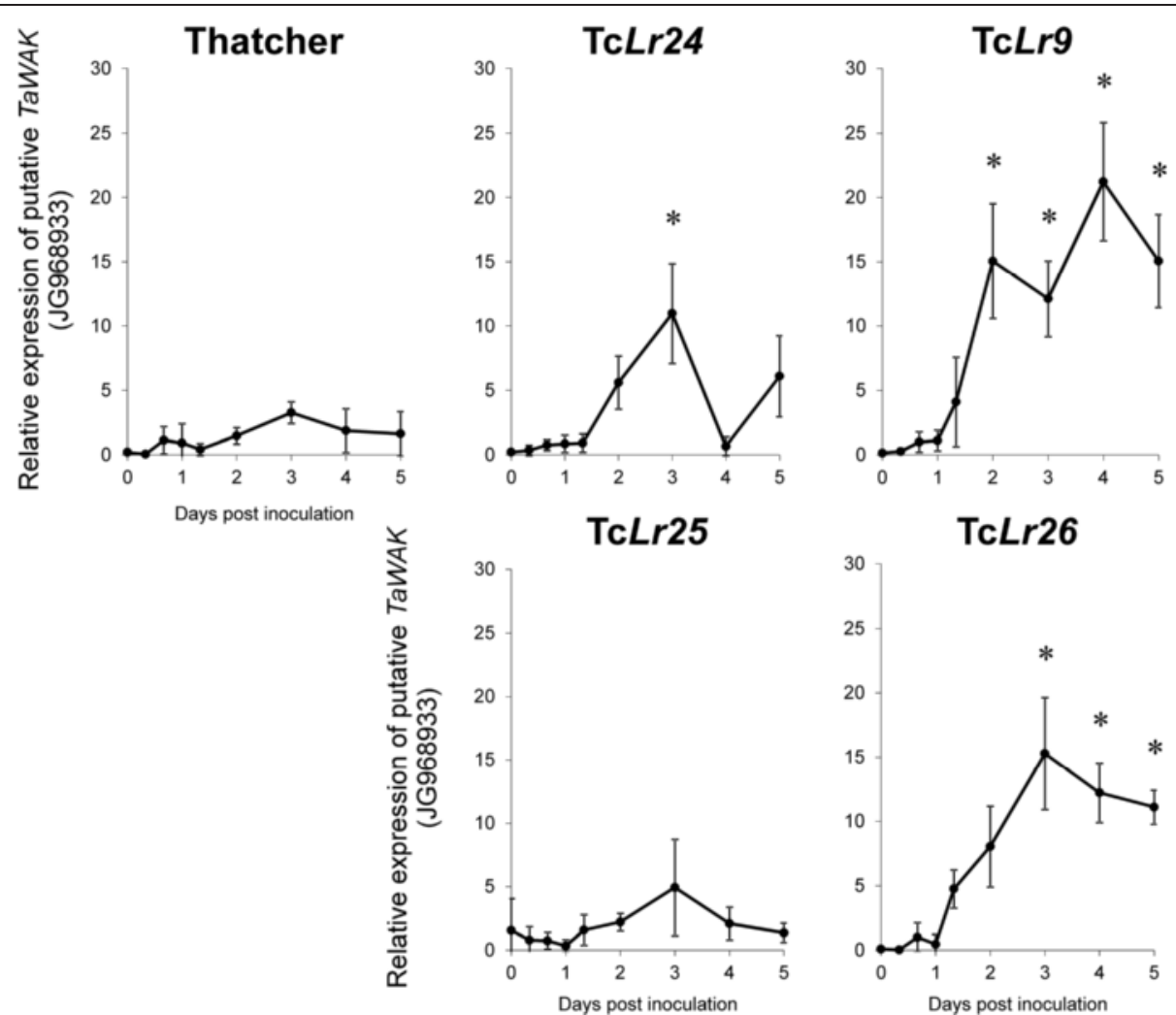

Fig. 7 Expression profile of the putative wall-associated kinase TaWAK (JG968933) in susceptible cultivar Thatcher, medium resistant (TcLr24, TcLr25) and highly resistant ( $T C L r 9, T C L r 26)$ isogenic lines. Data represent mean value of the relative transcript accumulation rate with standard deviation between the three independent biological repetitions. * - cumulative $p<0.05$ by analysis of variance (ANOVA) and $p<0.05$ Tuckey's test of $L r$ lines compared with Thatcher

by a cluster of 3 clones (JG968925_K818345_JG968926), shows pathogen-dependent temporal induction in both susceptible and resistant plants (Fig. 8e).

Expression of putative respiratory burst oxidase homo$\log$ Rboh (JG968934) is temporally induced in both tested lines, although the differences between the lines are not statistically significant (Fig. 8f). The C-terminal part of Rboh has affinity to 14-3-3 protein, which also binds $\mathrm{H}^{+}$-dependent ATPases. A clone with high similarity to wheat, barley and rice 14-3-3 protein (JG968969) shows transient induction 16 hpi in Thatcher and strong induction $32 \mathrm{hpi}$ in resistant TcLr9. Expression of the clone remains at an elevated level up to $5 \mathrm{dpi}$ (Fig. 8g).

The cumulative value of transcript rate was used to compare expression profiles of tested SSH clones and to evaluate their possible impact on plant-pathogen interaction. Among all clones the highest CVTR (770.4) was found for a clone encoding a calcium-mediated signaling protein (JG968925, Table 2, Fig. 8e). In the resistant line the value was $5.4 \mathrm{x}$ higher than in the susceptible Thatcher (Table 2). The CVTR for the remaining clones were low to intermediate (from 1.5 to 68.8 ). In resistant plants the values were from 1.5 to $5.5 \mathrm{x}$ higher compared with susceptible Thatcher. The highest $5.5 \mathrm{x}$ change of the CVTR was for the clone encoding wall-associated kinase (JG969003, Table 2, Fig. 8a).

\section{Discussion}

The SSH library was constructed using RNA isolated from leaves of isogenic lines - susceptible Thatcher and resistant Tc $L r 9$ - inoculated with a single spore isolate of $P$. triticina. The time points, based on histopathological observations, represented the most important steps of plant-pathogen interactions: a high ratio of germinating spores $(12 \mathrm{hpi})$, the beginning of haustorium mother cell (HMC) formation $(20 \mathrm{hpi})$, a high ratio of HMCs (26 hpi), the beginning of micronecrotic reactions (32 hpi) and a strong necrotic response (36 hpi). From the original 793 cDNA clones, 247 clones were selected after differential screening as the clones potentially involved in wheat-brown rust interaction. These clones represented putative defense response genes that were differentially regulated in wheat after infection with $P$. triticina.

Gross comparison of sequence annotation with the general profile for the wheat proteome [24] indicated 


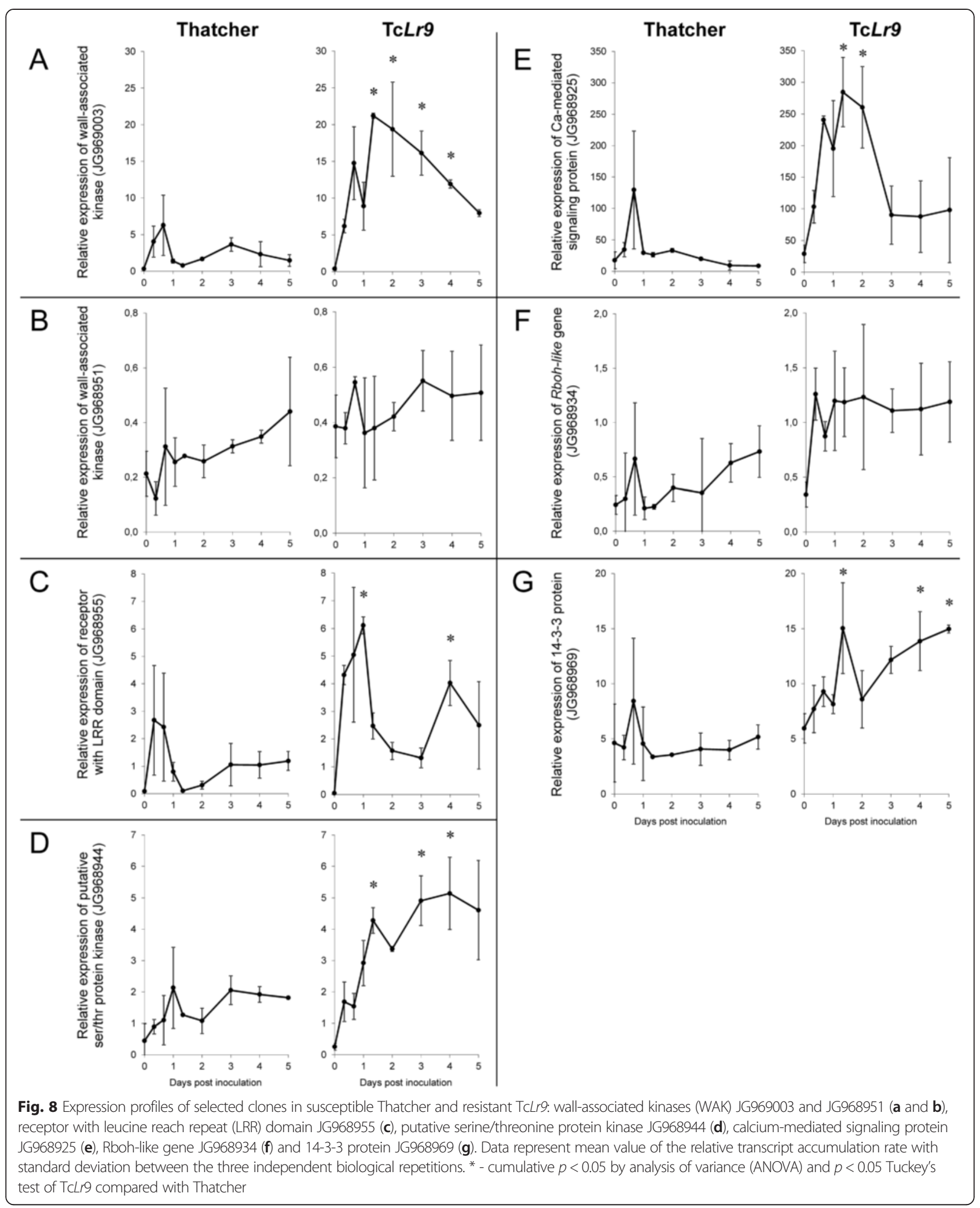

enrichment with sequences harboring functional domains involved in complex formation (e.g. protein, RNA and DNA binding) as well as catalytic activity (e.g. hydrolase kinase activity). Interestingly, proteins involved in 'transferase activity' seem to be less represented. Genes encoding proteins involved in 'structural activity' and 'transducer 
Table 1 Spearman correlation coefficient of ranked resistance levels and CVTRs of TaWAK clone JG968933

\begin{tabular}{|c|c|c|c|c|c|}
\hline \multirow{3}{*}{$\frac{\text { Isogenic lines }}{\text { Calculations }}$} & \multirow{3}{*}{$\begin{array}{l}\text { Group I } \\
\text { Susceptible } \\
\text { Thatcher }\end{array}$} & \multicolumn{2}{|c|}{ Group II } & \multicolumn{2}{|c|}{ Group III } \\
\hline & & \multicolumn{2}{|c|}{ Medium resistant } & \multicolumn{2}{|c|}{ Highly resistant } \\
\hline & & TCLr24 & TCLr25 & Tclrg & TCLr26 \\
\hline CVTR of TaWAK JG968933 (Fig. 7) & 8.1 & 20.4 & 11.2 & 56.3 & 42.6 \\
\hline Spearman correlation coefficient & 0.947 & & & & \\
\hline Significance level & $p=0.014$ & & & & \\
\hline
\end{tabular}

activity' were represented at similar levels when compared to the gross wheat Gene Ontology profile [24]. The detected profile of molecular activities provides a global overview of proteins involved in the mechanism of resistance in selected wheat lines.

Plant-pathogen interaction involves molecules/mechanisms representing different layers of plant defense, as defined by Jones and Dangle (2006) [37]. Pathogenassociated molecular patterns (PAMPs) or pathogenderived elicitors are recognized by host pattern recognition receptors (PRR), which facilitates efficient recognition of the pathogen by the host organism. Most PRRs characterized to date are receptor-like kinases (RLKs) possessing an extracellular domain, a transmembrane domain and a kinase domain. The characterization and annotation of the transcript identified in this study indicate that they can be categorized as defense-related due to their involvement in either basal defense or resistance through an $R$ gene mediated reaction.

The postulated successive steps leading to activation of the defense response include: host recognition of the pathogen followed by triggering of a signaling cascade involving MAP kinases, calcium ion fluxes [38], generation of ROS and oxidative burst [39], enforcing physical barriers by cell wall appositions [40], the hypersensitive response (HR) and cell death. The significant numbers of transcripts identified in this study represent components of this system.

Table 2 Cumulative values of transcript rates (CVTR) of selected $\mathrm{SSH}$ clones in susceptible Thatcher and resistant TCLr9 line

\begin{tabular}{lll}
\hline Isogenic line & \multicolumn{1}{l}{ CVTR } & \\
\cline { 2 - 3 } SSH clone & Thatcher & TCLr9 \\
\hline Wall-associated kinase JG969003 (Fig. 8a) & 12.4 & 68.8 \\
Wall-associated kinase JG968951 (Fig. 8b) & 1.5 & 2.3 \\
Receptor with leucine-rich repeat domain & 5.0 & 14.3 \\
JG968955 (Fig. 8c) & & 19.4 \\
$\begin{array}{l}\text { Putative serine/threonine protein kinase } \\
\text { JG968944 (Fig. 8d) } \\
\text { Calcium-mediated signaling protein }\end{array}$ & 7.9 & 770.4 \\
JG968925 (Fig. 8e) & 141.5 & \\
Rboh-like protein JG968934 (Fig. 8f) & & 5.6 \\
14-3-3 protein JG968969 (Fig. 8g) & 21.8 & 57.6 \\
\hline
\end{tabular}

Host recognition of pathogen infection is represented by several clones. The structure of the putative receptor with a nucleotide binding (NB) and leucine-rich repeat (LRR) domain (clone JG968955) is typical for most plant resistance $R$ proteins, and it may function in race-specific effector-triggered immunity as well as in basal resistance (reviewed previously [41, 42]). Expression of the clone, strongly and transiently induced in susceptible Thatcher and resistant $\operatorname{Tc} L r 9$ at the onset of appressoria formation (16 hpi. Fig. 8c), indicates a role in the pathogen recognition. The expression, significantly higher in TcLr9, indicates a function in rust resistance, possibly by interaction with $\operatorname{Lr} 9$ in a manner similar to $\operatorname{Lr} 10$, which depends on NBS-LRR encoding the RGA2 gene [43]. Pathogeninduced signal transduction activates a large group of protein kinases including MAP, WAK and NBS-LRR kinases. The following clones of the cDNA subtracted library represent Ser/Thr protein kinases: JG968978, JK818355, JK818407, JG968988, JG968943_JG968944, mitogenassociated protein kinases: JK818367, JG968966, receptor protein kinases with the NB-ARC domain JG968955 and wall-associated kinases: JG968951, JG968933_JK818362 and JG968950_JG969003. The putative serine/threonine protein kinase (clone JG968944) representing genes possibly involved in signaling is significantly higher upregulated in resistant TcLr9 than susceptible Thatcher (Fig. 8d). It is noteworthy that induction of the gene remains high 5 dpi despite no signs of pathogen structures on the leaves.

Five ESTs identified in the SSH library represent three transcripts (JG968933_JK818362, JG968951, JG969003_JG968950) of putative WAKs. The common structural features of WAK proteins are the cytoplasmically localized Ser/Thr kinase domain and extracellularly localized epidermal growth factor (EGF) domains. The WAK genes exist as large gene families. There are 26 WAK and WAK-like genes in Arabidopsis and 125 in rice [44]. It has been postulated that WAKs' ability to bind different types of pectins [45] and oligogalacturonides (OGs) [46] and subsequent activation of kinase domain facilitates the biological functions of the genes - i.e. regulation of cell elongation, morphogenesis, and plant immune responses $[46,47,48]$.

There are increasing numbers of reports indicating direct involvement of wall-associated kinases in signaling 
in the plant response to pathogen infection. In rice OsWAK1 was found to be induced by Magnaporthe ory$z a e$ and its functional analysis confirmed the crucial role of the gene in resistance against rice blast [49]. Molecules termed microbe-associated molecular patterns (MAMPs) and damage-induced molecular patterns (DAMPs) function as inducers of diverse layers of plant immune response: calcium-dependent signaling, production of reactive oxygen species (ROS) and induction of mitogen-activated protein kinase (MAPK) cascades [50]. The wall-associated kinase-encoding SIWAK1 was identified as a gene induced by MAMPs and functioning in tomato resistance against Pseudomonas syringae [51]. According to the authors, SIWAK1, a receptor of infection-generated OGs, triggers pathogen-induced signaling. Map-based cloning of $q H S R 1$ led to identification of the maize gene $Z m W A K$ encoding wall-associated kinase and conferring resistance to the soil-borne fungal pathogen Sporisorium reilianum [52]. It is worth noting that the gene confers quantitative resistance, which is very important in plant breeding because it is usually more durable then qualitative resistance conferred by major resistance genes [53].

The 3 wheat putative WAKs identified in the SSH library (JG968933, JG969003 and JG968951) are strongly induced by pathogen infection (Fig. 8a, b). Moreover, the expression profiles of TaWAK (JG968933) correlated with the resistance level, differentiating the three groups of genotypes: susceptible Thatcher from medium resistant (TcLr24, TcLr25) and highly resistant (TcLr9 and TcLr26) lines (Fig. 7). The high correlation coefficient between the TaWAK (JG968933) CVTRs and the level of the resistance is a strong indication for the important role in wheat resistance against brown rust. The function of the gene is currently under a detailed functional analysis. The presence of a $\mathrm{Ca}^{2+}$-binding domain in TaWAK (JG968933, Fig. 7) and the ability to bind OGs [46] indicate that this receptor kinase after perceiving pathogenderived signals (i.e. elicitors/OGs) can initiate oxidative burst through $\mathrm{Ca}^{2+}$ signaling. The feature provides the link with the following set of EST clones. Calcium ions act as a crucial second messenger in passing pathogeninduced signals from receptors (such as receptor kinases) to target molecules and activate defense reactions including $\mathrm{HR}[38,54,55]$. In the subtractive library calciumbinding molecules are represented by a relatively large group of ESTs encoding calmodulin-binding proteins/ calcium-binding proteins and calcium-transporting ATPases including those with $\mathrm{H}^{+} / \mathrm{Ca}^{2+}$ antiporter activity to restore the initially low concentration of $\mathrm{Ca}^{2+}$ ions in the cytoplasm. The following clones represent pathogen-regulated calcium transporting ATPases: JK818321_JK818338 and JG968975_JG968986, JG968929, JG968930_JG968931, JG969002_JG968938_JG968937.
Our previous results indicated that incompatible wheatbrown rust interaction was associated with activation of the two enzymatic systems peroxidases and NADPH oxidases known as respiratory burst oxidase homologs (Rboh) and accumulation of ROS in stomata and mesophyll cells around the infection site [10]. Rboh are plasma membrane proteins directly controlled by calcium ions through N-terminal EF-hand calcium-binding motifs [56]. Cytosolic $\mathrm{Ca}^{2+}$ spiking, which precedes pathogen-induced defense responses, is a likely factor initiating Rboh activity and oxidative burst [57]. Expression of the Rboh-like encoding gene (JG968934) correlates very well with the pattern of oxidative burst in the susceptible Thatcher and the resistant TcLr9 line [10, 11].

Biphasic expression of the calcium-mediated signaling clone (JG968925, Fig. 8e) and $\mathrm{H}_{2} \mathrm{O}_{2}$ generating Rboh (JG968934, Fig. 8f) is similar to the pattern of cytosolic calcium influx detected in Arabidopsis plants challenged by $P$. syringae [58]. This agrees with a concept postulating that close localization of the $\mathrm{Rboh}$ and the $\mathrm{Ca}^{2+}$ channels facilitates close control of oxidative burst in sites adjacent to pathogen infection [55]. It is also compatible with the observation of calcium-dependent activation of Rboh (NADPH oxidase) and $\mathrm{H}_{2} \mathrm{O}_{2}$ generation in OG-treated N. plumbaginifilia [59]. In our system the biphasic pattern of processes observed in wheat-rust interaction is evident: the first peak of the expression (Fig. 8a-g) and the accumulation of ROS in stomata correlates well with formation of appressoria on stomata [10]. The second expression signal, detected only in the TcLr9 resistant line, correlates with oxidative burst in mesophyll cells and micronecrotic/hypersensitive (HR) reactions [10]. It is worth noting that one of the two identified WAKs (JG968933) with a possible role in calcium signaling (calcium ion binding identified by GO analysis) showed strong induction during the incompatible wheat-rust interaction (Fig. 7). The results indicate that the identified TaWAK might function as the receptor of OGs (which are possible components of PAMPs) and also as the calcium signaling component.

Phosphatidic acid (PA) acts as a functional molecule and secondary messenger in pathogen-induced phospholipid signaling [60]. The PA-dependent pathway intertwines with calcium signaling. It activates the MAP kinase cascade and triggers oxidative burst by recruiting functional NADPH-complex (Rboh) at the plasma membrane [60]. The components of this pathway are represented by SSH clones encoding phospholipase D (JG968992, JK818323_JK818358) and phosphatidylcholine cytidylyltransferase (JG968942, JG968943_JG968944). The Rac/Rop GTPases (small GTPases) constitute part of a large and divergent group of monomeric GTP-binding proteins (mG-proteins) and act as important components of plant immunity. They form protein complexes with 
chaperones Hsp90 and Hsp70 [61] and function as molecular switches interconnecting ROS generating systems, calcium signaling and cell wall enforcement [62]. Rice Rac GTPase OsRac1 was found to be involved in ROS generation by directly interacting in a calcium-dependent manner with the N-terminal region of Rboh (NADPH oxidase) [63]. Monomeric GTP-binding proteins are represented in SSH library by the following clones: JG969001, JK818377, JG969000, JG968940, JG969002_JG968938_ JG968937, JG968995_JG968994_JG968993, JG968948_ JG968961, JK818408 and JG968940.

Chaperones play an important role in plant resistance by maintaining cell homeostasis during infection. Many chaperones have been identified as heat shock proteins (Hsp), and some of them, such as Hsp60, Hsp70 and Hsp90, were defined as pathogen-related (PR) proteins. It has been found that wheat resistance to Puccinia graminis conferred by the TaRLK-R gene [64] and wheat resistance to $P$. triticina conferred by Lr21 [65] are functionally dependent on Hsp90s [66]. The following identified cDNA clones have heat shock protein signatures with putative chaperone functionalities: JK818328, JK818388, JG968981 and JK818410.

Another group of components of the immune network constitutes 14-3-3 proteins. They act as intracellular signal molecules coordinating different signaling pathways. They participate in regulation of ROS production by direct interaction with Rboh (NADPH oxidase) and coregulation by small GTPase of the Rac family [67]. By regulation of pathogen-induced oxidative burst the 14-3-3 proteins also positively regulate programmed cell death (PCD)/HR [68]. Expression of 14-3-3 encoding genes was reported during incompatible barley-powdery mildew [69] and soybeanPseudomonas syringae [70] interactions. The 14-3-3 proteins are encoded by JG968970 and JG968969 clones. The expression profile of the 14-3-3 encoding clone (JG968969) with induction during the first phase of wheat-rust interaction and strong up-regulation only in resistant TcLr9 (Fig. 8g) confirms its involvement in rust resistance.

All considered, the subtractive library contains ESTs with a demonstrated or highly probable role in plantpathogen interaction and represents wheat transcripts differentially regulated during plant-pathogen interaction, which participate in the most important pathways involved in the plant response to pathogen infection. Further detailed analysis of the relevant genes should provide new information about mechanisms of wheat resistance to rust infection and supply novel candidates for modern plant breeding using molecular techniques.

\section{Conclusions}

The SSH library represents transcripts regulated by pathogen infection during compatible and incompatible interactions of susceptible Thatcher and resistant $\operatorname{Lr} 9$ with Puccinia triticina.

Annotation of selected clones confirmed their putative roles in the successive steps of plant-pathogen interactions. This included pathogen recognition, pathogeninduced signaling and resistance processes such as cell wall enforcement, oxidative burst and micronecrotic reactions.

Among the clones strongly up-regulated during incompatible interaction were the transcripts of wall-associated kinases, which due to their transmembrane localization might function as signal transducers, the transcripts involved in calcium-mediated signaling and the transcripts encoding Rboh-like proteins with possible roles in oxidative burst and micronecrotic reactions.

\section{Additional files}

Additional file 1 : Table S4. Infection types of selected isogenic wheat lines inoculated with single spore isolate of Puccinia triticina (brown rust) used in this study. Infection type scale: 0 - no uredinia or other macroscopic signs of infection, 0 ; - no uredinia, but hypersensitive necrotic or chlorotic flecks of varying size present, 1 - small uredinia often surrounded by necrosis, 2 - small to medium-sized uredinia often surrounded by chlorosis or necrosis, 3 - medium-sized uredinia associated with chlorosis or rarely necrosis, 4 - large uredinia without chlorosis or necrosis. (DOCX 19 kb)

Additional file 2: Table S1. Primers and reaction conditions used for PCR. (DOCX $18 \mathrm{~kb}$ )

Additional file 3: Table S2. Expression sequence tags of wheat (line TCLr9) after inoculation with brown rust (Puccinia triticina) deposited in GenBank http://www.ncbi.nlm.nih.gov/Genbank. (DOCX 18 kb)

Additional file 4: Table S3. Gross functional annotation of EST tags. (XLS 95 kb)

\section{Abbreviations}

CVTR: Cumulative value of transcript rate; dpi: Days post inoculation; GO: Gene ontology; HMC: Haustorium mother cell; hpi: Hours post inoculation; PAMP: Pathogen-associated molecular patterns; PRR: Pattern recognition receptors; $\mathrm{PPCR}$ : Quantitative PCR; Rboh: Respiratory burst oxidase homologue; RT-PCR: Reverse transcription polymerase chain reaction; SSH: Suppression subtractive hybridization; WAK: Wall-associated kinase.

\section{Competing interests}

The authors declare that they have no competing interests.

\section{Authors' contributions}

MD-B carried out most of the experiments: pathogen inoculation, histopathology, host-pathogen observations, molecular analysis; SA coding sequence prediction, annotation of proteins and noncoding RNAS, Gene Ontology classification; YY and UP expression profiling of SSH clones; EL construction of SSH library, identification of differentially expressed clones; AN-O contributed to conception and discussion of the project, and participated in manuscript writing; WMK contributed to the conception of gross functional annotation, discussion of the results, and manuscript writing; WO contributed to conception of the project, analysis and interpretation of the results, and writing the manuscript. All authors read and approved the final manuscript.

Funding

The research was funded by National Research Council grant no. UMO-2011/ 01/B/NZ9/02387

\section{Author details}

${ }^{1}$ Department of Genetic Engineering, Plant Breeding and Acclimatization, Institute - National Research Institute, Radzikow 05-870 Blonie, Poland. 
${ }^{2}$ Department of Computational Biology, Institute of Molecular Biology and Biotechnology, Faculty of Biology, Adam Mickiewicz University, Umultowska 89, 61-614 Poznan, Poland. ${ }^{3}$ Department of Functional Genomics, Plant Breeding and Acclimatization, Institute - National Research Institute, Radzikow, 05-870 Blonie, Poland.

Received: 19 March 2015 Accepted: 16 September 2015 Published online: 05 October 2015

\section{References}

1. Bolton MD, Kolmer JA, Garvin DF. Wheat leaf rust caused by Puccinia triticina. Mol Plant Pathol. 2008;9(5):563-75.

2. Singh D, Mohler V, Park RF. Discovery, characterisation and mapping of wheat leaf rust resistance gene Lr71. Euphytica. 2013;190(1):131-6.

3. Cloutier S, McCallum BD, Loutre C, Banks TW, Wicker T, Feuillet C, et al. Leaf rust resistance gene $L r 1$, isolated from bread wheat (Triticum aestivum $L$.) is a member of the large psr567 gene family. Plant Mol Biol. 2007;65(1-2):93-106.

4. Feuillet C, Travella S, Stein N, Albar L, Nublat A, Keller B. Map-based isolation of the leaf rust disease resistance gene Lr10 from the hexaploid wheat (Triticum aestivum L.) genome. Proc Natl Acad Sci U S A. 2003;100(25):15253-8.

5. Huang L, Brooks SA, Li W, Fellers JP, Trick HN, Gill BS. Map-based cloning of leaf rust resistance gene $L r 21$ from the large and polyploid genome of bread wheat. Genetics. 2003;164(2):655-64

6. Krattinger SG, Lagudah ES, Spielmeyer W, Singh RP, Huerta-Espino J, McFadden $\mathrm{H}$, et al. A Putative ABC Transporter Confers Durable Resistance to Multiple Fungal Pathogens in Wheat. Science. 2009;323(5919):1360-3.

7. Kloppers FJ, Pretorius ZA. Effects of combinations amongst genes Lr13, Lr34 and $L$ r37 on components of resistance in wheat to leaf rust. Plant Pathol. 1997:46(5):737-50.

8. Sears ER. The transfer of leaf-rust resistance from Aegilops umbellulata to wheat. Brookhaven Symp Biol. 1956;1956:1-22.

9. Nocente F, Gazza L, Pasquini M. Evaluation of leaf rust resistance genes Lr1, Lr9, Lr24, Lr47 and their introgression into common wheat cultivars by marker-assisted selection. Euphytica. 2006;155(3):329-36.

10. Orczyk W, Dmochowska-Boguta M, Czembor HJ, Nadolska-Orczyk A. Spatiotemporal patterns of oxidative burst and micronecrosis in resistance of wheat to brown rust infection. Plant Pathol. 2010;59(3):567-75.

11. Dmochowska-Boguta M, Nadolska-Orczyk A, Orczyk W. Roles of peroxidases and NADPH oxidases in the oxidative response of wheat (Triticum aestivum) to brown rust (Puccinia triticina) infection. Plant Pathol. 2013;62(5):993-1002.

12. Sanchez-Torres P, Gonzalez-Candelas L. Isolation and characterization of genes differentially expressed during the interaction between apple fruit and Pencillium expansum. Mol Plant Pathol. 2003;4(6):447-57.

13. Zhang L, Meakin H, Dickinson M. Isolation of genes expressed during compatible interactions between leaf rust (Puccinia triticina) and wheat using CDNA-AFLP. Mol Plant Pathol. 2003;4(6):469-77.

14. Fofana B, Banks TW, McCallum B, Strelkov SE, Cloutier S. Temporal gene expression profiling of the wheat leaf rust pathosystem using CDNA microarray reveals differences in compatible and incompatible defence pathways. Int J Plant Genomics. 2007;2007:17542.

15. Kong L, Anderson JM, Ohm HW. Induction of wheat defense and stressrelated genes in response to Fusarium graminearum. Genome. 2005;48(1):29-40.

16. Cheng Z, Tang K, Yan H, Fu J, Ying F, Huang X. Analysis of differentially expressed genes in Oryza meyerianain response to infection by Xanthomonas oryzae pv. oryzae. Plant Breed. 2009;4:393-9.

17. Bogacki P, Oldach KH, Williams KJ. Expression profiling and mapping of defence response genes associated with the barley-Pyrenophora teres incompatible interaction. Mol Plant Pathol. 2008;9(5):645-60.

18. Schiliro E, Ferrara M, Nigro F, Mercado-Blanco J. Genetic Responses Induced in Olive Roots upon Colonization by the Biocontrol Endophytic Bacterium Pseudomonas fluorescens PICF7. PLoS One. 2012;7:11

19. McIntosh RAWCR, Park RF. Wheat rusts : an atlas of resistance genes Australia: CSIRO; 1995.

20. Siebert PD, Chenchik A. Modified Acid Guanidinium Thiocyanate Phenol Chloroform Rna Extraction Method Which Greatly Reduces DNA Contamination. Nucleic Acids Res. 1993;21(8):2019-20.

21. Gasparis S, Orczyk W, Zalewski W, Nadolska-Orczyk A. The RNA-mediated silencing of one of the Pin genes in allohexaploid wheat simultaneously decreases the expression of the other, and increases grain hardness. J Exp Bot. 2011;62(11):4025-36.

22. Huang X, Madan A. CAP3: A DNA sequence assembly program. Genome Res. 1999;9(9):868-77.

23. Walenz B, Florea L. Sim4db and Leaff: utilities for fast batch spliced alignment and sequence indexing. Bioinformatics. 2011;27(13):1869-70.

24. Brenchley R, Spannagl M, Pfeifer M, Barker GLA, D'Amore R, Allen AM, et al. Analysis of the bread wheat genome using whole-genome shotgun sequencing. Nature. 2012;491(7426):705-10.

25. Grigoriev IV, Nikitin R, Haridas S, Kuo A, Ohm R, Otillar R, et al. MycoCosm portal: gearing up for 1000 fungal genomes. Nucleic Acids Res. 2014;42(D1):D699-704

26. Kersey PJ, Lawson D, Birney E, Derwent PS, Haimel M, Herrero J, et al. Ensembl Genomes: Extending Ensembl across the taxonomic space. Nucleic Acids Res. 2010;38:D563-9.

27. Lottaz C, Iseli C, Jongeneel CV, Bucher P. Modeling sequencing errors by combining Hidden Markov models. Bioinformatics. 2003 Oct;19 Suppl 2:ii103-12.

28. Altschul SF, Madden TL, Schaffer AA, Zhang J, Zhang Z, Miller W, et al. Gapped BLAST and PSI-BLAST: a new generation of protein database search programs. Nucleic Acids Res. 1997;25(17):3389-402.

29. Griffiths-Jones S, Bateman A, Marshall M, Khanna A, Eddy SR. Rfam: an RNA family database. Nucleic Acids Res. 2003;31(1):439-41.

30. Jurka J. Repbase update: a database and an electronic journal of repetitive elements. Trends Genet. 2000;16(9):418-20.

31. Zhi-Liang HBJ, Reecy JM. CateGOrizer: A Web-Based Program to Batch Analyze Gene Ontology Classification Categories. Online J Bioinform. 2008;9(2):108-12.

32. Eddy SR. Accelerated Profile HMM Searches. Plos Comput Biol. 2011;7(10):e1002195

33. Sonnhammer EL, Eddy SR, Durbin R. Pfam: a comprehensive database of protein domain families based on seed alignments. Proteins. 1997:28(3):405-20.

34. Wicker T, Matthews DE, Keller B. TREP: a database for Triticeae repetitive elements. Trends Plant Sci. 2002;7(12):561-2.

35. Meyers BC, Axtell MJ, Bartel B, Bartel DP, Baulcombe D, Bowman JL, et al. Criteria for annotation of plant MicroRNAs. Plant Cell. 2008;20(12):3186-90.

36. Barrett T, Troup DB, Wilhite SE, Ledoux P, Rudnev D, Evangelista C, et al. NCBI GEO: mining tens of millions of expression profilesdatabase and tools update. Nucleic Acids Res. 2007;35(Database issue):D760-765.

37. Jones JD, Dangl JL. The plant immune system. Nature. 2006;444(7117):323-9.

38. Frei dit Frey $N$, Mbengue $M$, Kwaaitaal M, Nitsch L, Altenbach D, Haweker H, et al. Plasma membrane calcium ATPases are important components of receptor-mediated signaling in plant immune responses and development Plant Physiol. 2012;159(2):798-809.

39. Apel K, Hirt H. Reactive oxygen species: Metabolism, oxidative stress, and signal transduction. Annu Rev Plant Biol. 2004;55:373-99.

40. Underwood $\mathbf{W}$. The plant cell wall: a dynamic barrier against pathogen invasion. Front Plant Sci. 2012;3.

41. Belkhadir Y, Subramaniam R, Dangl JL. Plant disease resistance protein signaling NBS-LRR proteins and their partners. Curr Opin Plant Biol. 2004:7(4):391-9.

42. Dodds PN, Rathjen JP. Plant immunity: towards an integrated view of plantpathogen interactions. Nat Rev Genet. 2010;11(8):539-48.

43. Loutre C, Wicker T, Travella S, Galli P, Scofield S, Fahima T, et al. Two different CC-NBS-LRR genes are required for Lr10-mediated leaf rust resistance in tetraploid and hexaploid wheat. Plant J. 2009;60(6):1043-54

44. Zhang S, Chen C, Li L, Meng L, Singh J, Jiang N, et al. Evolutionary expansion, gene structure, and expression of the rice wall-associated kinase gene family. Plant Physiol. 2005;139(3):1107-24.

45. Kohorn BD, Kohorn SL. The cell wall-associated kinases, WAKs, as pectin receptors. Front Plant Sci. 2012;3.

46. Brutus A, Sicilia F, Macone A, Cervone F, De Lorenzo G. A domain swap approach reveals a role of the plant wall-associated kinase 1 (WAK1) as a receptor of oligogalacturonides. Proc Natl Acad Sci U S A. 2010;107(20):9452-7.

47. Kohorn BD, Johansen S, Shishido A, Todorova T, Martinez R, Defeo E, et al. Pectin activation of MAP kinase and gene expression is WAK2 dependent. Plant J 2009:60(6):974-982

48. Diener AC, Ausubel FM. RESISTANCE TO FUSARIUM OXYSPORUM 1, a dominant Arabidopsis disease-resistance gene, is not race specific. Genetics. 2005;171(1):305-21. 
49. Li H, Zhou SY, Zhao WS, Su SC, Peng YL. A novel wall-associated receptor-like protein kinase gene, OsWAK1, plays important roles in rice blast disease resistance. Plant Mol Biol. 2009;69(3):337-46

50. Segonzac C, Zipfel C. Activation of plant pattern-recognition receptors by bacteria. Curr Opin Microbiol. 2011;14(1):54-61.

51. Rosli HG, Zheng Y, Pombo MA, Zhong SL, Bombarely A, Fei ZJ, et al. Transcriptomics-based screen for genes induced by flagellin and repressed by pathogen effectors identifies a cell wall-associated kinase involved in plant immunity. Genome Biol. 2013;14:12.

52. Zuo W, Chao Q, Zhang N, Ye J, Tan G, Li B, et al. A maize wall-associated kinase confers quantitative resistance to head smut. Nat Genet. 2015;47(2):151-7.

53. Ayliffe $M$, Singh $R$, Lagudah E. Durable resistance to wheat stem rust needed. Curr Opin Plant Biol. 2008;11(2):187-92.

54. Heath MC. Hypersensitive response-related death. Plant Mol Biol. 2000:44(3):321-34

55. Lecourieux D, Raneva R, Pugin A. Calcium in plant defence-signalling pathways. New Phytologist. 2006;171(2):249-69.

56. Sagi M, Fluhr R. Production of reactive oxygen species by plant NADPH oxidases. Plant Physiol. 2006;141 (2):336-40.

57. Zhao J, Davis $L C$, Verpoorte R. Elicitor signal transduction leading to production of plant secondary metabolites. Biotechnol Adv. 2005;23(4):283-333.

58. Nemchinov LG, Shabala L, Shabala S. Calcium efflux as a component of the hypersensitive response of Nicotiana benthamiana to Pseudomonas syringae. Plant Cell Physiol. 2008:49(1):40-6.

59. Lecourieux D, Mazars C, Pauly N, Ranjeva R, Pugin A. Analysis and effects of cytosolic free calcium increases in response to elicitors in Nicotiana plumbaginifolia cells. Plant Cell. 2002;14(10):2627-41.

60. Laxalt AM, Munnik T. Phospholipid signalling in plant defence. Curr Opin Plant Biol. 2002;5(4):332-8.

61. Thao NP, Chen L, Nakashima A, Hara SI, Umemura K, Takahashi A, et al. RAR1 and HSP90 form a complex with Rac/Rop GTPase and function in innate-immune responses in rice. Plant Cell. 2007;19(12):4035-45.

62. Chen L, Shiotani K, Togashi T, Miki D, Aoyama M, Wong HL, et al. Analysis of the Rac/Rop small GTPase family in rice: expression, subcellular localization and role in disease resistance. Plant Cell Physiol. 2010;51(4):585-95.

63. Wong HL, Pinontoan R, Hayashi K, Tabata R, Yaeno T, Hasegawa K, et al. Regulation of rice NADPH oxidase by binding of Rac GTPase to its N-terminal extension. Plant Cell. 2007;19(12):4022-34.

64. Zhou H, Li S, Deng Z, Wang X, Chen T, Zhang J, et al. Molecular analysis of three new receptor-like kinase genes from hexaploid wheat and evidence for their participation in the wheat hypersensitive response to stripe rust fungus infection. Plant J. 2007;52(3):420-34.

65. Scofield SR, Huang L, Brandt AS, Gill BS. Development of a virus-induced gene-silencing system for hexaploid wheat and its use in functional analysis of the L 221 -mediated leaf rust resistance pathway. Plant Physiol. 2005;138(4):2165-73.

66. Boter M, Amigues B, Peart J, Breuer C, Kadota Y, Casais C, et al. Structural and functional analysis of SGT1 reveals that its interaction with HSP90 is required for the accumulation of $R x$, an $R$ protein involved in plant immunity. Plant Cell. 2007;19(11):3791-804.

67. Elmayan T, Fromentin J, Riondet C, Alcaraz G, Blein JP, Simon-Plas F. Regulation of reactive oxygen species production by a 14-3-3 protein in elicited tobacco cells. Plant Cell Environ. 2007;30(6):722-32.

68. Oh CS, Pedley KF, Martin GB. Tomato 14-3-3 protein 7 positively regulates immunity-associated programmed cell death by enhancing protein abundance and signaling ability of MAPKKK \{alpha\}. Plant Cell. 2010;22(1):260-72

69. Finnie $C$, Andersen $\mathrm{CH}$, Borch J, Gjetting S, Christensen AB, de Boer AH, et al. Do 14-3-3 proteins and plasma membrane $\mathrm{H}+$-ATPases interact in the barley epidermis in response to the barley powdery mildew fungus? Plant Mol Biol. 2002;49(2):137-47.

70. Seehaus K, Tenhaken R. Cloning of genes by mRNA differential display induced during the hypersensitive reaction of soybean after inoculation with Pseudomonas syringae pv. glycinea. Plant Mol Biol. 1998;38(6):1225-34.

\section{Submit your next manuscript to BioMed Central and take full advantage of:}

- Convenient online submission

- Thorough peer review

- No space constraints or color figure charges

- Immediate publication on acceptance

- Inclusion in PubMed, CAS, Scopus and Google Scholar

- Research which is freely available for redistribution

Submit your manuscript at www.biomedcentral.com/submit 